AKUNTABILITAS

Vol. VII No. 1, April 2014

P.ISSN: $1979-858 \mathrm{X}$

Halaman $26-41$

\title{
/INITIAL RETURN: PERBEDAAN SAHAM SYARIAH DAN NON SYARIAH DI PASAR MODAL INDONESIA
}

\author{
Renny Wulandari \\ Universitas Panca Bhakti Pontianak
}

\begin{abstract}
This research is based on the phenomenon initial public offering, initial return. The purpose of this paper is to find empirical evidence about the influence of stock offering percentage, offer size, profitability, firm size, IPO risk, financial leverage and liquidity, between syari'a stock and non syari'a stock in the Indonesian Stock Exchange. This research use Regression Model and Chow Test to test the hypothesis which has developed. The result showed variable IPO risk have positive effect on initial return of syari'a stock and variable financial leverage and current ratio have positive effect on initial return of non syrai'a stock. Conclusion of this research showed that there were different factors that influenced initial return between syari'a stock and non syari'a stock. Contibutions for future studies should use other predictor variables and append observation years to get much sample for the research.
\end{abstract}

Keywords: Syari'a and non Syari'a Stocks, (Initial Public Offering) IPO, Initial return

\begin{abstract}
ABSTRAK: Penelitian ini didasarkan pada fenomena penawaran umum perdana, initial return . Tujuan dari makalah ini adalah untuk menemukan bukti empiris tentang pengaruh persentase penawaran saham , menawarkan ukuran, profitabilitas , ukuran perusahaan , risiko IPO , leverage keuangan dan likuiditas , antara saham syari'a dan saham non syari'a di Bursa Efek Indonesia . Penelitian ini menggunakan Model Regresi dan Chow Test untuk menguji hipotesis yang telah dikembangkan . Hasil penelitian menunjukkan risiko variabel IPO memiliki efek positif pada pengembalian awal saham syari'a dan variabel leverage keuangan dan rasio lancar berpengaruh positif pada pengembalian awal saham non syrai'a . Kesimpulan dari penelitian ini menunjukkan bahwa ada faktor yang berbeda yang mempengaruhi initial return antara saham syari'a dan saham non syari'a . Iuran untuk studi di masa depan harus menggunakan variabel prediktor lain dan menambahkan pengamatan tahun untuk mendapatkan banyak sampel untuk penelitian .
\end{abstract}

Kata kunci: Saham Syariah dan Non Syariah, (Initial Public Offering) IPO, Initial return

\footnotetext{
"Draft pertama: 15 Januari 2014; Revisi: 10 Februari 2014; Diterima: 12 Maret 2014

Penulis dapat dikontak melalui: renny.wulandari@yahoo.com
} 


\section{PENDAHULUAN}

Pemenuhan kebutuhan dana merupakan suatu hal yang tidak dapat dipisahkan dari perusahaan untuk menjalankan kegiatan operasinya. Perusahaan memiliki berbagai alternatif sumber pendanaan, baik yang berasal dari dalam maupun dari luar perusahaan. Alternatif pendanaan dari dalam perusahaan, umumnya dengan menggunakan laba yang ditahan perusahaan sedangkan alternatif pendanaan dari luar perusahaan dapat berasal dari kreditur berupa utang maupun pendanaan yang bersifat penyertaan dalam bentuk saham (equity). Pendanaan melalui mekanisme penyertaan umumnya dilakukan dengan menjual saham perusahaan kepada masyarakat atau biasa dikenal dengan go public (Sunariyah, 2011).

Dalam pasar modal tersebut usaha untuk mendapatkan dana dapat dilakukan dengan cara perusahaan mengeluarkan surat berharga atau saham yang baru dikeluarkan oleh perusahaan tersebut dijual pada pasar primer yang berupa initial public offering (IPO) atau penawaran perdana terhadap sahamnya atau dapat pula dengan cara menambah surat berharga baru jika perusahaan tersebut sudah going public. Selanjutnya surat berharga yang telah beredar diperdagangkan di pasar sekunder (Isfatun dan Hatta, 2010).

Dalam perusahaan yang go public biasanya mengalami permasalahan, yaitu fenomena underpricing. Underpricing merupakan fenomena harga rendah yang terjadi karena penawaran perdana ke publik yang secara rerata murah (Hartono, 2010). Hal ini sering diakibatkan adanya informasi yang asimetri antara perusahaan emiten dengan penjamin emisi (model baron) atau antara investor yang informed dan uninformed (model Rock) (Isfaatun dan Hatta, 2010). Fenomena underpricing merupakan fenomena yang umum di dunia, tanpa terkecuali di Indonesia. Pengamatan terhadap aktivitas IPO (initial public offering) di bursa efek Indonesia selama tahun 1990-2008 menunjukkan bahwa telah terjadi fenomena underpricing yang signifikan (Arifin, 2007).

Dalam Arifin (2007) fenomena underpricing didokumentasikan sebelumnya oleh Ibbotson (1975). Dengan menggunakan data di pasar modal Amerika Serikat tahun 19601969, Ibbotson (1975) menemukan rata-rata underpricing sebesar 11,4\%. Namun pada penelitian terbaru yang dilakukan Ibbotson et al. (1993) yang menemukan rata-rata underpricing sebesar 15,3\% pada periode tahun 1960-1992. Menurut Sembel (1996), fenomena underpricing ini tidak hanya terjadi di Amerika Serikat, tetapi juga di pasar modal di luar Amerika Serikat.

Pada tahun 2006-2012 tercatat ada 138 perusahaan melakukan IPO di Bursa Efek Indonesia, 117 perusahaan diantaranya mengalami underpricing dan 18 perusahaan lainnya mengalami overpricing atau dapat dikatakan $98.662 \%$ perusahaan yang go public sejak tahun 2006 hingga 2012 mengalami underpricing dengan rata-rata underpricing per tahun mencapai $35.904 \%$. Untuk lebih memudahkan, berikut ini disajikan tingkat underpricing yang terjadi pada tahun 2006-2012.

Banyak variabel yang mempengaruhi underpricing pada saat perusahaan melakukan initial public offering (IPO) di pasar modal. Mengetahui faktor yang mempengaruhi underpricing akan dapat menghindarkan perusahaan yang akan go public terhadap kerugian karena underestimate atas nilai pasar sahamnya. Mengenai faktor-faktor yang mempengaruhi underpricing telah dilakukan banyak penelitian. Penelitian yang dilakukan oleh (Sulistio, 2005) yang menguji pengaruh akuntansi dan non akuntansi terhadap initial return sebagai proksi dari keputusan investasi pada perusahaan yang melakukan initial public offering (IPO) di Bursa Efek Jakarta. Informasi akuntansi yang digunakan dalam penelitian meliputi ukuran perusahaan, earning per share, price earning ratio dan tingkat leverage. Informasi non akuntansi yang digunakan meliputi prosentase pemegang saham lama, reputasi auditor dan reputasi underwriter. Hasil penelitian menunjukkan bahwa 
informasi akuntansi yang berpengaruh terhadap initial return adalah tingkat leverege, sedangkan informasi non akuntansi yang berpengaruh terhadap initial return adalah prosentase pemegang saham.

Hasil penelitian yang dilakukan oleh Yong dan Rahim (2010) di Malaysia yang meneliti faktor-faktor yang telah memberi kontribusi pada tingkat underpricing IPO di Malaysia termasuk demand (permintaan), penawaran dan pengaruh ukuran perusahaan serta jenis penawaran dan risiko untuk IPO saham syariah, yang terpisah dari saham nonsyariah. Berkaitan dengan status syariah, IPO pada subsampel syariah menggunakan variabel yang sama dengan saham non syariah. Hasil penelitian menunjukkan bahwa initial return dari saham syariah, ukuran dan jenis penawaran berpengaruh negatif terhadap initial return dan risiko berpengaruh positif terhadap initial return sedangkan untuk saham non syariah risiko berpengaruh negatif terhadap initial return.

Berdasarkan uraian diatas, peneliti tertarik untuk melakukan penelitian tentang faktor-faktor yang mempengaruhi initial return dalam konteks syariah, meskipun peneliti masih menemukan kendala karena penelitian tentang underpricing dalam konteks syariah masih sangat terbatas dan belum pernah diteliti pada pasar modal di Indonesia.

\section{KERANGKA TEORITIS DAN PENGEMBANGAN HIPOTESIS Teori Sinyal dan Asimetri Informasi}

Teori sinyal (signaling theory) menyatakan bahwa perusahaan yang berkualitas baik dengan sengaja akan memberikan sinyal pada pasar, dengan demikian pasar diharapkan dapat membedakan perusahaan yang berkualitas baik dan buruk (separating equibilirium). Pada saat melakukan penawaran umum, calon investor tidak sepenuhnya dapat membedakan perusahaan yang berkualitas baik dan buruk. Oleh karena itu, emiten dan penjamin emisi dengan sengaja akan memberi sinyal kepada pasar yang merupakan sinyal positif yang berusaha diberikan oleh emiten guna menunjukkan kualitas perusahaan pada saat IPO (Sumarso, 2003, dalam Zebua, 2012).

Teori signaling dikembangkan dalam ilmu ekonomi dan keuangan untuk memperhitungkan kenyataan bahwa orang-orang dalam (insiders) perusahaan pada umumnya memiliki informasi yang lebih baik dan lebih cepat berkaitan dengan kondisi mutakhir dan prospek perusahaan dibandingkan dengan investor luar. Munculnya information asymmetric tersebut menyulitkan investor dalam menilai secara obyektif berkaitan dengan kualitas perusahaan. Pernyataan-pernyataan yang dibuat manajer diragukan kebenarannya karena baik perusahaan buruk maupun perusahaan bagus akan sama-sama mengklaim bahwa prospek perusahaannya bagus. Karena pembuktian benar salahnya pernyataan tersebut membutuhkan waktu maka orang-dalam perusahaan akan dapat mengambil keuntungan atas pernyataan-pernyataannya yang tidak benar jika klaimklaim tersebut dipercaya oleh investor luar. Munculnya masalah information asymmetric ini membuat investor secara rata-rata memberikan penilaian yang lebih rendah terhadap semua saham perusahaan (Arifin, 2007).

\section{Persentase Penawaran Saham (PPS) dan Initial return}

Salah satu bentuk peningkatan modal disetor suatu perseroan dalam penawaran umum terbatas (right issues), perseroan menawarkan hak kepada pemegang saham yang ada untuk mendapatkan saham baru yang tentu saja berarti menyetor modal dengan rasio tertentu. Jika pemegang saham tersebut tidak mengambil haknya, maka ia dapat menjual haknya tersebut kepada investor lain, dengan demikian di pasar modal juga dikenal perdagangan right. Jadi rights adalah hak yang diberikan kepada pemegang saham lama untuk terlebih dahulu membeli saham baru yang dikeluarkan dengan tujuan agar para 
pemegang saham lama diberi kesempatan untuk mempertahankan persentase kepemilikannya dalam suatu perusahaan (Zebua, 2012). Persentase kepemilikan saham yang ditahan oleh pemilik (insiders) menunjukkan adanya private information yang dimiliki oleh pemilik atau manajer (Leland \& Phyle, 1977). Informasi tingkat kepemilikan saham oleh entrepreneur akan digunakan oleh investor sebagai pertanda atau signal tentang keadaan perusahaan.

Persentase penawaran saham dapat digunakan sebagai proxy terhadap faktor ketidakpastian return saham yang akan diterima oleh investor dan calon investor. Semakin besar persentase saham yang ditahan perusahaan maka semakin besar pula tingkat underpriced yang mengakibatkan semakin besarnya tingkat ketidakpastian harga saham di masa akan datang (Carter et al., 1998). Dalam rangka pengambilan keputusan investasi, calon investor membutuhkan banyak informasi guna mempertimbangkan membeli atau tidak membeli saham yang ditawarkan perusahaan emiten.

Berdasarkan penjelasan diatas maka diajukan hipotesis sebagai berikut:

$\mathbf{H}_{1 \mathbf{a}}$ : Persentase penawaran saham berpengaruh positif terhadap initial return saham syariah.

$\mathbf{H}_{\mathbf{1 b}}$ : Persentase penawaran saham berpengaruh positif terhadap initial return saham non syariah.

\section{Nilai Penawaran Saham (NPS) dan Initial return}

Pada saat perusahaan menawarkan saham baru maka terdapat aliran kas masuk dari procceds (penerimaan dan pengeluaran saham). Procceds menunjukan besarnya ukuran penawaran saham pada saat IPO. Nilai penawaran saham yang ditawarkan ke publik memberikan informasi sejauh mana kebutuhan keuangan perusahaan. Semakin tinggi perusahaan dikembangkan akan semakin tinggi jumlah dana yang dibutuhkan. Nilai penawaran saham juga akan menjadikan pertimbangan investor seberapa besar dana yang dibutuhkan untuk menguasai saham dalam persentase tertentu. Perusahaan dengan skala usaha yang besar dan tingkat pertumbuhan yang tinggi akan cenderung menawarkan saham dengan nilai yang besar demikian pula sebaliknya perusahaan yang baru berdiri dengan tingkat pertumbuhan usaha yang relative kecil akan menawarkan saham dengan nilai yang kecil pula. Perhitungan nilai penawaran saham dirumuskan sebagai berikut (Triani dan Hikmah 2006) dimana nilai penawaran saham (Offersize) diukur dengan nilai penawaran saham perusahaan pada saat melakukan IPO yang telah dibagi dengan nilai ekuitas perusahaan.

Berdasarkan penjelasan diatas, maka diajukan hipotesis sebagai berikut:

$\mathbf{H}_{2 \mathbf{a}}$ : Nilai penawaran saham berpengaruh positif terhadap initial return saham syariah.

$\mathbf{H}_{\mathbf{2}}$ : Nilai penawaran saham berpengaruh positif terhadap initial return saham non syariah.

\section{Profitabilitas dan Initial return}

Salah satu ratio profitabilitas adalah earning per share (penghasilan per lembar saham). Earning per share adalah rasio yang menunjukkan berapa besar kemampuan per lembar saham dalam menghasilkan laba (Syafri, 2008). Rasio ini menunjukkan kemampuan perusahaan untuk memberikan imbalan pada setiap lembar saham biasa. Informasi mengenai kemampuan perusahaan dalam menghasilkan pendapatan dapat membantu investor untuk menilai kemampuan perusahaan dalam menghasilkan arus kas yang baik di masa mendatang. Pada umumnya pemegang saham dan calon investor akan tertarik pada earning per share, karena earning per share menggambarkan jumlah uang yang diperoleh untuk setiap lembar saham dan earning per share yang besar menjadi 
indikator keberhasilan dari emiten. Perhitungan earning per share dirumuskan laba bersih dibagi jumlah lembar saham yang beredar (Rahardjo, 2009).

Rasio earning per share yang semakin meningkat memberikan indikasi bahwa semakin besar keuntungan yang diperoleh per lembar saham, dengan asumsi outstandingshares tetap atau semakin besar kemungkinan perusahaan dalam memperoleh laba sehingga kemungkinan membayarkan deviden juga semakin besar ataupun diinvestasikan lagi (retained earning). Maka diharapkan akan memperoleh hasil yang semakin besar dimasa mendatang. Harapan tersebut mengakibatkan meningkatnya earning per share akan meningkatkan pendapatan saham. Profitabilitas yang tinggi suatu perusahaan mengurangi ketidakpastian bagi investor sehingga menurunkan tingkat underpricing (Kim et. al dalam Zebua, 2012).

Berdasarkan uraian diatas maka diajukan hipotesis sebagai berikut:

$\mathbf{H}_{\mathbf{3 a}}$ : Profitabilitas berpengaruh negatif terhadap initial return saham syariah

$\mathbf{H}_{\mathbf{3} \mathbf{b}}$ : Profitabilitas berpengaruh negatif terhadap initial return saham non syariah

\section{Ukuran Perusahaan dan Initial return}

Ukuran perusahaan merupakan cerminan potensi perusahaan dalam menghasilkan arus kas dan kemampuan untuk mengakses informasi yang lebih besar. Ukuran perusahaan merupakan nilai yang menentukan besar atau kecilnya perusahaan yang ditunjukkan dengan total aset yang dimilikinya. Pengukuran dengan menggunakan total aktiva dianggap lebih baik dari total penjualan karena total aktiva lebih stabil dari total penjualan serta lebih menunjukkan kekayaan perusahaan yang digunakan untuk mencapai tujuan perusahaan. Perusahaan yang berskala besar cenderung lebih dikenal masyarakat sehingga informasi mengenai prospek perusahaan berskala besar lebih mudah diperoleh investor daripada perusahaan berskala kecil. Variabel perusahaan diukur dengan menghitung log natural total aktiva tahun terakhir sebelum perusahaan tersebut listing (Suyatmin, 2006).

Ukuran perusahaan yang besar mengindikasikan bahwa perusahaan dalam keadaan yang stabil (Dianingsih, 2003). Menurut Siregar dan Utama (2006), semakin besar ukuran perusahaan, informasi yang tersedia untuk investor dalam pengambilan keputusan sehubungan dengan investasi saham semakin banyak. Beatty, 1989 dalam Ayu, 2012, mengemukakan bahwa ukuran perusahaan berpengaruh signifikan dan negatif pada tingkat underpricing. Hal ini menunjukkan bahwa ukuran perusahaan dijadikan proxy ketidakpastian karena perusahaan besar umumnya lebih dikenal oleh masyarakat daripada perusahaan kecil.

Berdasarkan uraian diatas maka diajukan hipotesis sebagai berikut:

$\mathbf{H}_{\mathbf{4 a}}$ : Ukuran perusahaan berpengaruh negatif terhadap initial return saham syariah.

$\mathbf{H}_{\mathbf{4}}$ : Ukuran perusahaan berpengaruh negatif terhadap initial return saham non syariah.

\section{Risiko IPO dan Initial return}

Risiko sering dihubungkan dengan penyimpangan atau deviasi dari outcome yang diterima dengan yang di ekspektasi. (Van horne dan Wachowics Jr, 1992 dalam Hartono, 2010) mendefinisikan risiko sebagai variabilitas return terhadap return yang diharapkan. Risiko adalah tingkat potensi kerugian yang timbul karena perolehan hasil investasi yang diharapkan tidak sesuai dengan harapan (Rahardjo, 2006).

Para investor banyak yang menyukai adanya risiko yang tinggi karena dalam risiko yang tinggi tersebut cenderung terdapat potensi tingkat return yang tinggi pula. Konsep ini dikenal dengan istilah "high return high risk, low return low risk" konsep ini mengatakan bahwa setiap potensi keuntungan tinggi yang mungkin diperoleh cenderung menyimpan potensi kerugian yang tinggi, sementara potensi return yang relatif normal akan 
memberikan tingkat risiko kerugian yang relatif rendah pula (Makaryanawati dan Ulum, 2009).

Hanya menghitung return saja untuk suatu investasi tidaklah cukup. Risiko dari investasi juga perlu diperhitungkan. Return dan risiko merupakan dua hal yang tidak terpisah, karena pertimbangan suatu investasi merupakan trade-off dari kedua faktor ini. Return dan risiko mempunyai hubungan yang positif, semakin besar risiko yang harus ditanggung, semakin besar return yang harus dikompensasikan (Hartono, 2010).

Oleh karena itu hipotesis yang diajukan sebagai berikut:

$\mathbf{H}_{\mathbf{5} \mathbf{a}}$ : Risiko berpengaruh positif terhadap initial return saham syariah

$\mathbf{H}_{\mathbf{5 b}}$ : Risiko berpengaruh positif terhadap initial return saham non syariah

\section{Financial Leverage dan Initial return}

Menurut Sartono (dalam Ekadjaja 2009), financial leverage adalah rasio jumlah hutang dengan beban tetap terhadap aktiva atau rasio jumlah utang terhadap modal sendiri. Ukuran lain terhadap financial leverage, terutama adalah yang berkaitan dengan penerimaan kas terhadap kebutuhan pengeluaran kas. Financial leverage menunjukkan kemampuan perusahaan dalam membayar hutangnya dengan equity yang dimiliki oleh perusahaan (Yasa, 2005).

Total utang mencakup baik utang lancar maupun utang jangka panjang, kreditur lebih menyukai rasio utang yang rendah karena semakin rendah rasio ini maka semakin besar perlindungan terhadap kerugian kreditur dalam peristiwa likuidasi (Setianingrum, 2005).

Oleh karena itu hipotesis yang diajukan adalah sebagai berikut:

$\mathbf{H}_{\mathbf{6} \mathbf{a}}$ : Financial leverage berpengaruh positif terhadap initial return saham syariah.

$\mathbf{H}_{\mathbf{6}}$ : Financial leverage berpengaruh positif terhadap initial return saham non syariah.

\section{Likuiditas dan Initial return}

Likuiditas adalah masalah yang berhubungan dengan masalah kemampuan suatu perusahaan untuk memenuhi kewajiban financialnya yang segera harus dipenuhi (Riyanto, 2008). Rasio likuiditas merupakan suatu indikator mengenai kemampuan perusahaan membayar semua kewajiban financial jangka pendek saat jatuh tempo dengan menggunakan aktiva lancar yang tersedia.

Berdasarkan uraian di atas maka peneliti mendasari penalaran pada teori signaling, yakni untuk mengatasi masalah penilaian yang rendah terhadap harga saham, maka perusahaan dapat memberikan sinyal kepada investor bahwa perusahaan tersebut memiliki current ratioyang tinggi. Current ratio yang tinggi menunjukkan kemampuan perusahaan dalam memenuhi kewajiban jangka pendeknya sehingga mengurangi risiko yang harus ditanggung oleh perusahaan. Hal ini menjadikan risiko yang ditanggung pemegang saham juga semakin kecil. Jadi semakin besar current ratio underpricing semakin kecil.

Oleh karena itu diajukan hipotesis sebagai berikut:

$\mathbf{H}_{7 \mathbf{a}}$ : Likuiditas berpengaruh negatif terhadap initial return saham syariah.

$\mathbf{H}_{7 \mathbf{b}}$ : Likuiditas berpengaruh negatif terhadap initial return saham non syariah.

\section{Pengaruh Variabel Independen terhadap Initial return Saham Syariah dan non Syariah}

Untuk mengetahui variabel independen berpengaruh secara simultan terhadap initial return maka diajukan hipotesis sebagai berikut: 
$\mathbf{H}_{\mathbf{8 a}}$ : Persentase penawaran saham, nilai penawaran saham, profitabilitas, ukuran perusahaan, risiko IPO, financial levereage, likuiditas berpengaruh secara bersamasama terhadap initial return saham syariah.

$\mathbf{H}_{\mathbf{8 b}}$ : Persentase penawaran saham, nilai penawaran saham, profitabilitas, ukuran perusahaan, risiko IPO, financial levereage, likuiditas berpengaruh secara bersamasama terhadap initial return saham non syariah.

\section{Perbedaan Initial return antara Saham Syariah dan non Syariah}

Yumettasari, Widiastuti, dan Mawardi (2006), hasil penelitiannya menunjukkan terdapat perbedaan pengaruh dari current ratio, debt to equity ratio, inventory turn over, return on equity, net profit margin, dan devident payout ratio dalam mempengaruhi price earning ratio antara saham syariah dan non syariah kategori non keuangan.

Obsevasi penelitian ini dibedakan menjadi dua kelompok yaitu syariah dan non syariah. Penelitian ini menguji apakah nilai pengaruh variabel-variabel dependen (initial return) dari dua sektor tersebut bernilai beda. Oleh karena itu, hipotesis yang diajukan sebagai berikut:

H9: Ada perbedaan pengaruh persentase penawaran saham, nilai penawaran saham, ukuran perusahan, profitabilitas, financial leverage, risiko, likuiditas terhadap initial return saham syariah dengan saham non syariah.

\section{METODE PENELITIAN}

\section{Pengumpulan Data}

Populasi dalam penelitian ini adalah perusahaan yang melakukan penawaran umum perdana (IPO) yang telah tercatat di Bursa Efek Indonesia pada periode 2008-2012. Total sampel dalam penelitian ini adalah 104 perusahan yang melakukan IPO tahun 2008-2012 dan yang memenuhi kriteria sebanyak 72 perusahaan. Pemilihan sampel dalam penelitian ini menggunakan metode purposive sampling, yaitu metode pemilihan sampel dengan kriteria tertentu.

Jenis data yang digunakan dalam penelitian ini adalah data sekunder, yaitu data rasio keuangan, ukuran perusahaan, persentase penawaran saham, nilai penawaran saham, risiko IPO, dan harga saham tahun 2008-2012. Data-data tersebut akan diperoleh dari prospektus perusahaan, Indonesian Capital Market Directory (ICMD), e-Bursa.com, dan http//www.idx.co.id.

\section{Definisi Operasional dan Pengukuran Variabel}

Dependen variabel dalam penelitian ini adalah Initial return yang merupakan selisih antara harga penawaran umum (offering price) dengan harga penutupan dipasar sekunder pada hari pertama (closing price).

Variabel Independen untuk Persentase Permintaan Penawaran Besarnya didefinisikan sebagai perbandingan antara jumlah saham yang dijual kepada masyarakat pada saat IPO dengan total saham beredar. Nilai Penawaran saham (Proceeds) menunjukkan besarnya skala penawaran saham pada saat IPO. Ukuran Perusahaan diukur dengan besarnya aset yang dimiliki perusahaan. Profitabilitas Mengukur seberapa besar dividen per lembar saham yang akan dibagikan kepada investor setelah dikurangi dengan dividen bagi para pemilik perusahaan. Risiko IPO merupakan Risiko perusahaan dalam menerbitkan saham. Financial Leverage merupakan kemampuan perusahaan dalam melunasi semua kewajiban. Likuiditas (current ratio) mengukur likuiditas suatu perusahaan. 


\section{Teknik Analisis Data}

Data dalam penelitian ini dianalisis dengan menggunakan:

Pengujian Hipotesis

Ketepatan fungsi regresi sampel dalam menaksir nilai aktual dapat diukur dari goodness of fit nya. Secara statistik, setidaknya ini dapat diukur dari nilai koefisien determinasi $\left(\mathrm{R}^{2}\right)$, statistik $\mathrm{F}$ dan nilai statistik t. Perhitungan statistik disebut signifikan secara statistik, apabila uji nilai statistiknya berada dalam daerah kritis (daerah dimana Ho ditolak) dan sebaliknya.

Analisis Regresi Berganda

Model yang digunakan dalam penelitian ini sebagai berikut:

$$
\begin{aligned}
\mathrm{IR}= & \alpha+\beta 1 \mathrm{PPS}+\beta 2 \mathrm{NPS}+\beta 3 \mathrm{UK}+\beta 4 \mathrm{PRO}+\beta 5 \mathrm{Risk}+\beta 6 \mathrm{FL}+ \\
& \beta 7 \mathrm{LIQ}+\mathrm{e}
\end{aligned}
$$

Keterangan:

$\begin{array}{ll}\text { IR } & =\text { Initial return } \\ \alpha & =\text { Konstanta } \\ \beta_{1}-\beta_{7} & =\text { Koefisien Regresi } \\ \text { PPS } & =\text { Persentase Penawaran Saham } \\ \text { NPS } & =\text { Nilai Persentase Saham } \\ \text { UK } & =\text { Ukuran Perusahaan } \\ \text { PRO } & =\text { Profitabilitas } \\ \text { Risk } & =\text { Risiko IPO } \\ \text { FL } & =\text { Financial Leverage } \\ \text { LIQ } & =\text { Likuiditas }\end{array}$

Uji Chow Test

Rumus dari uji chow test ini adalah sebagai berikut:

$$
\mathbf{F}=\frac{(\mathbf{R S S r}-\mathbf{R S S u r}) / \mathrm{k}}{\text { RSSur } /(\mathbf{n} 1+\mathbf{n} 2-2 \mathrm{k})}
$$

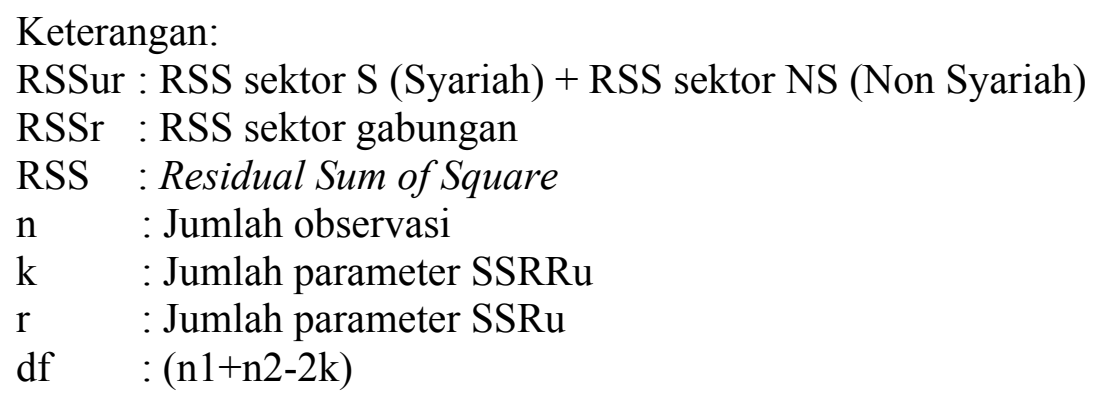

\section{HASIL DAN PEMBAHASAN}

\section{Statistik Deskriptif Variabel Penelitian}

Untuk initial return dalam saham syariah dan saham non syariah mempunyai nilai rata-rata 28,716 . Untuk rata-rata initial return yang didapat pada www.e-bursa.com dari tahun 2008-2012 mempunyai nilai rata-rata 27,36. Oleh karena itu, sampel data dalam penelitian dapat dikatakan representatif atau dengan kata lain dapat mewakili seluruh populasi. 


\section{Pengujian Asumsi Klasik Saham Syariah}

Uji Normalitas Nilai Kolmogorov-Smirnov sebesar 0,504 dan tidak signifikan pada 0,05 karena $(\mathrm{p}=0,961>0,0504)$. Jadi $\mathrm{H}_{0}$ tidak dapat ditolak, sehingga residual berdistribusi dengan normal. Jadi secara keseluruhan dapat disimpulkan bahwa model regresi telah lolos uji normalitas.

Dengan melihat VIF (Variance Infloating Factor) variabel bebas lebih kecil dari 10, maka pada model regresi yang terbentuk tidak terjadi gejala multikolinier. Uji Heteroskedastisitas diketahui bahwa pada model regresi tidak terjadi gejala heteroskedastisitas. Hal ini karena signifikansi variabel untuk saham syariah menunjukkan nilai $>0,05$. Uji Otokorelasi Pada output model summary terdapat nilai durbin watson sebesar 2,120. Pengambilan keputusan pada asumsi ini memerlukan dua nilai bantu yang diperoleh dari tabel Durbin Watson, yaitu nilai $\mathrm{dL}$ dan $\mathrm{dU}$, dengan $\mathrm{K}=\mathrm{jumlah}$ variabel bebas dan $n=u k u r a n$ sampel. Jika nilai Durbin watson beerada di antara nilai dU hingga (4$\mathrm{dU}$ ) berarti tidak terjadi otokorelaso terpenuhi. Dari output diatas dengan $n=46, K=7$ maka akan diproleh nilai $\mathrm{dL1}, 189$ dan $\mathrm{dU}$ 1,895 sehingga nilai 4-dU $=2,105$ dan 4 -dL $=2,811$ maka dapat disimpulkan bahwa model persamaan regresi tidak ada korelasi negatif tanpa keputusan atau bisa disebut dengan tidak terjadi otokorelasi.

\section{Pengujian Asumsi Klasik Saham non Syariah}

Uji Normalitas Untuk saham non syariah hasil uji dengan nilai signifikansi (2-tailed) sebesar $0,837>0,05$. Oleh karena itu $\mathrm{H} 0$ tidak dapat ditolak. Hal itu berarti nilai residual terstandarisasi dinyatakan menyebar secara normal. Multikolinieritas Untuk saham non syariah karena nilai VIF nya lebih kecil dari 10 dan nilai TOL lebih besar dari 0,1 maka pada model yang terbentuk tidak terjadi gejala multikolinier. Heteroskedastisitas Untuk saham syariah diketahui bahwa pada model regresi tidak terjadi gejala heteroskedastisitas. Hal ini karena signifikansi variabel untuk saham syariah menunjukkan nilai $>0,05$ sedangkan untuk saham non syariah nilai sig. Variabelnya juga $>0,05$. autokorelasi Pada output model summary terdapat nilai durbin watson sebesar 2,047. Pengambilan keputusan pada asumsi ini memerlukan dua nilai bantu yang diperoleh dari tabel Durbin Watson, yaitu nilai $\mathrm{dL}$ dan $\mathrm{dU}$, dengan $\mathrm{K}=$ jumlah variabel bebas dan $\mathrm{n}=\mathrm{ukuran}$ sampel. Jika nilai Durbin watson beerada di antara nilai dU hingga (4-dU) berarti tidak terjadi autokorelaso terpenuhi. Dari output diatas dengan $\mathrm{n}=26, \mathrm{~K}=7$ maka akan diproleh nilai dL0,816 dan $\mathrm{dU}$ 2,117 sehingga nilai 4-dU $=1,883$ dan $4-\mathrm{dL}=3,184$ maka dapat disimpulkan bahwa model persamaan regresi tidak ada korelasi positif tanpa keputusan atau bisa disebut dengan tidak terjadi autokorelasi.

\section{Koefisien Determinasi dan Uji Kelayakan Model Regresi Saham Syariah}

Nilai R Adjusted Square sebesar untuk saham syariah adalah 0,218 atau sebesar $21,8 \%$. Hal ini menunjukkan variabel independen yang digunakan dalam model mampu menjelaskan sebesar $21,8 \%$ variasi variabel dependen dan $78,2 \%$ dijelaskan oleh variabel lainnya diluar model.

Sementara itu, nilai $\mathrm{F}$ hitung sebesar 2,797 dengan probabilitas 0,019. Karena probabilitas jauh lebih kecil dari 0,05 maka model regresi dapat digunakan untuk memprediksi variabel dependen.

\section{Koefisien Determinasi dan Uji Kelayakan Model Regresi Saham Non Syariah}

Untuk saham non syariah mempunyai nilai $\mathrm{R}$ adjusted square sebesar 0,356 atau sebesar $35,6 \%$. Hal ini menunjukkan bahwa variasi variabel independen yang digunakan 
dalam model mampu menjelaskan sebesar 35,6\% variasi variabel dependen dan $64,4 \%$ sisanya dijelaskan oleh variabel lainnya diluar model.

Hasil uji $\mathrm{F}$ didapat $\mathrm{F}$ hitung sebesar 2,971 dengan probabilitas 0,030. Karena probabilitas jauh lebih kecil dari 0,05 maka model regresi dapat digunakan untuk memprediksi variabel dependen.

\section{Pengujian Hipotesis}

Hipotesis pertama menyatakan ada pengaruh positif persentase penawaran saham terhadap initial return saham syariah dan non syariah. Diperoleh nilai t hitung sebesar $0,169<$ nilai t tabel 1,68 dengan signifikansi variabel persentase penawaran saham 0,867 lebih besar dari 0,05 . Dengan demikian dapat disimpulkan $\mathrm{H}_{1 \mathrm{a}}$ ditolak, yang artinya bahwa variabel persentase penawaran saham tidak berpengaruh positif terhadap initial return saham syariah dan tidak signifikan atau dengan kata lain persentase penawaran saham tidak berpengaruh signifikan terhadap initial return saham syariah. Sedangkan untuk saham non syariah diperoleh nilai t hitung sebesar 3,24 > nilai $t$ tabel 1,73 dengan signifikansi variabel persentase penawaran saham 0,750 lebih besar dari 0,05. Dengan demikian dapat disimpulkan bahwa $\mathrm{H}_{1 \mathrm{~b}}$ ditolak. Yang artinya bahwa variabel persentase penawaran saham memiliki pengaruh positif terhadap initial return saham non syariah namun tidak signifikan atau dengan kata lain persentase penawaran saham tidak berpengaruh terhadap initial return saham non syariah.

Hipotesis kedua menyatakan ada pengaruh positif nilai penawaran saham terhadap initial return saham syariah dan non syariah. Nilai t hitung diperoleh sebesar $-0,773>$ nilai t tabel $-1,68$, dengan signifikansi variabel nilai penawaran saham 0,444 lebih besar dari 0,05. Dengan demikian disimpulkan $\mathrm{H}_{2 \mathrm{a}}$ ditolak yang artinya bahwa variabel nilai penawaran saham tidak berpengaruh positif terhadap initial return saham syariah dan tidak signifikan atau dengan kata lain nilai penawaran saham tidak berpengaruh signifikan terhadap initial return saham syariah. Sementara itu, nilai t hitung pada saham non syariah sebesar $0,129<$ nilai t tabel 1,73 dengan signifikansi variabel nilai penawaran saham 0 , 899 lebih besar dari 0,05. Maka dapat disimpulkan bahwa variabel nilai penawaran saham tidak berpengaruh positif dan tidak signifikan terhadap initial return saham non syariah, atau dengan kata lain nilai penawaran saham tidak berpengaruh terhadap initial return saham non syariah.

Hipotesis ketiga menyatakan ada pengaruh negatif earning per share terhadap initial return saham syariah dan non syariah. Hasil uji untuk saham syairah diperoleh nilai $\mathrm{t}$ hitung sebesar 0,628 > nilai t tabel -1,68 dengan signifikansi variabel earning per share 0,534 lebih besar dari 0,05. Maka dapat disimpulkan bahwa variabel earning per share tidak memiliki pengaruh negatif terhadap initial return saham syariah namun tidak signifikan atau dengan kata lain earning per share tidak berpengaruh terhadap initial return saham syariah. Selanjutnya, nilai t hitung untuk saham non syariah sebesar 1,487 > nilai t tabel -1,73 dengan signifikansi variabel earning per share 0, 154 lebih besar dari 0,05. Dengan demikian dapat disimpulkan bahwa $\mathrm{H}_{3 \mathrm{~b}}$ ditolak, yang artinya bahwa variabel earning per share tidak memiliki pengaruh negatif terhadap initial return saham non syariah namun tidak signifikan. Dengan kata lain earning per share tidak berpengaruh terhadap initial return saham non syariah.

Hipotesis keempat menyatakan ada pengaruh negatif ukuran perusahaan terhadap initial return saham syariah dan non syariah. Saham syariah diperoleh nilai t hitung sebesar $0,799>$ nilai t tabel -1,68 dengan signifikansi variabel ukuran perusahaan 0,429 lebih besar dari 0,05 . Dengan demikian dapat disimpulkan $\mathrm{H}_{4 \mathrm{a}}$ ditolak yang artinya bahwa ukuran perusahaan tidak berpengaruh negatif dan tidak signifikan terhadap initial return saham 
syariah atau dengan kata lain ukuran perusahaan tidak berpengaruh terhadap initial return saham syariah. Sementara itu, untuk saham non syariah diperoleh nilai $t$ hitung sebesar $0,53>$ nilai t tabel $-1,73$ dengan signifikansi variabel ukuran perusahaan 0,958 lebih besar dari 0,05 . Dengan demikian dapat disimpulkan $\mathrm{H}_{4 \mathrm{~b}}$ ditolak yang artinya bahwa variabel ukuran perusahaan tidak memiliki pengaruh negatif terhadap initial return saham non syariah dan tidak signifikan atau dengan kata lain ukuran perusahaan tidak berpengaruh terhadap initial return saham non syariah.

Hipotesis kelima menyatakan ada pengaruh positif risiko IPO terhadap initial return saham syariah dan non syariah. Diperoleh nilai t hitung untuk saham syariah sebesar 2,234 $>$ nilai t tabel 1,68 dengan signifikansi variabel risiko IPO 0,031 lebih kecil dari 0,05. Maka dapat disimpulkan $\mathrm{H}_{5 \mathrm{a}}$ diterima yang artinya bahwa variabel risiko IPO memiliki pengaruh positif terhadap initial return saham syariah dan signifikan secara statistik. Berbeda halnya dengan saham non syariah yang mempunyai nilai t hitung sebesar $1,419<$ nilai t tabel 1,73 dengan signifikansi variabel risiko IPO 0,173 lebih besar dari 0,05. Hal ini menunjukkan $\mathrm{H}_{5 \mathrm{~b}}$ ditolak yang artinya variabel risiko IPO tidak memiliki pengaruh positif terhadap initial return saham non syariah dan tidak signifikan atau dengan kata lain Risiko IPO tidak berpengaruh signifikan terhadap Initial return saham non syariah.

Hipotesis keenam menyatakan ada pengaruh negatif financial leverage terhadap initial return saham syariah dan non syariah. Hasil diperoleh nilai t hitung sebesar $-0,274$ untuk saham syariah $>$ nilai t tabel -1,68 dengan signifikansi variabel financial leverage 0 , 786 lebih besar dari 0,05. Maka dapat disimpulkan bahwa $\mathrm{H}_{6 \mathrm{a}}$ ditolak yang artinya bahwa variabel financial leverage memiliki pengaruh positif terhadap initial return saham syariah namun tidak signifikan, atau dengan kata lain financial leverage tidak berpengaruh terhadap initial return saham syariah. Berbeda dengan saham non syariah yang mempunyai nilai $\mathrm{t}$ hitung sebesar 3,24 > nilai $\mathrm{t}$ tabel 1,73 dengan signifikansi variabel financial leverage 0,004 lebih kecil dari 0,05 . Artinya, $\mathrm{H}_{6 \mathrm{~b}}$ diterima yang artinya bahwa variabel financial leverage memiliki pengaruh positif terhadap initial return saham non syariah dan signifikan secara statistik.

Hipotesis ketujuh menyatakan ada pengaruh negatif current ratio terhadap initial return saham syariah dan non syariah. Untuk saham syariah diperoleh nilai t hitung sebesar 1,650 > nilai t tabel -1,68 dengan signifikansi variabel current ratio 0, 107 lebih besar dari 0,05. Maka dapat disimpulkan $\mathrm{H}_{7 \mathrm{a}}$ ditolak yang artinya bahwa variabel current ratio tidak memiliki pengaruh negatif terhadap initial return saham syariah. Begitu juga untuk saham non syariah, nilai $t$ hitung sebesar 2,406 > nilai t tabel 1,73 dengan signifikansi variabel current ratio 0, 027 lebih besar dari 0,05. Maka dapat disimpulkan $\mathrm{H}_{7 \mathrm{~b}}$ ditolak yang artinya bahwa variabel current ratio berpengaruh terhadap initial return saham non syariah dan signifikan.

Sementara itu, hasil pengujian simultan menunjukkan nilai $\mathrm{F}$ hitung sebesar 2,797 ( $>$ $\mathrm{F}$ tabel $=2$, 216) untuk saham syariah dengan probabilitas 0,019 , dan $\mathrm{F}$ hitung sebesar $2,971(>\mathrm{F}$ tabel $=2,388)$ untuk saham non syariah dengan probabilitas 0,030 . Hasil ini menunjukkan bahwa penggunaan rasio keuangan dan non keuangan sebagai alat analisis keuangan dan non keuangan dapat digunakan untuk mengukur perubahan initial return dalam saham syariah maupun non syariah. Dengan demikian mendukung $\mathrm{H}_{8 \mathrm{a}}$ dan $\mathrm{H}_{8 \mathrm{~b}}$.

\section{Analisis Perbedaan Pengaruh Variabel Independen Terhadap Initial return Saham Syariah dan Non Syariah (Chow Test)}

Chow test adalah alat untuk menguji test for equality of coefficients atau uji kesamaan koefisien. Uji ini ditemukan oleh George Chow. Uji ini digunakan apabila observasi yang dilakukan dapat dikelompokkan dalam 2 kelompok (Ghozali, 2006), dan 
penelitian ini membagi objek penelitian menjadi dua sektor yaitu syariah dan non syariah. Peneliti ingin membandingkan apakah ada kesamaan pengaruh variabel-variabel independen terhadap variabel dependen antara sektor syariah dan non syariah.

Dari tabel $\mathrm{F}$ dengan $\mathrm{df}=8$ dan 56 tingkat signifikansi 0,05 di dapat nilai $\mathrm{F}$ tabel sebesar 2,20. Oleh karena Fhitung $>$ Ftabel dapat disimpulkan bahwa terdapat perbedaan pengaruh persentase penawaran saham, nilai penawaran saham, earning per share, ukuran perusahaan, risiko IPO, financial leverage, dan current ratio dalam memengaruhi initial return antara saham syariah dan saham non syariah.

\section{SIMPULAN}

Dari faktor-faktor yang diuji untuk saham syariah, hanya variabel risiko IPO saja yang memengaruhi initial return. Pada umumnya setiap perusahaan yang melakukan penawaran saham perdana memiliki risiko untuk underpricing, semakin banyak saham yang dilepaskan maka semakin tinggi akan risiko terjadinya underpricing, karena investasi saham syariah masih dalam perkembangan di Indonesia. Hal ini merupakan signal positif bagi investor yang akan memperoleh initial return yang tinggi. Sehingga investor memperhitungkan informasi ini sebagai dasar dalam menentukan keputusan investasinya.

Untuk faktor-faktor yang diuji untuk saham non syariah, terdapat dua variabel yang berpengaruh terhadap initial return. Berdasarkan hasil analisis hanya variabel financial leverage yang sama dengan hipotesis penelitian. Financial leverage merupakan rasio utang terhadap modal sendiri. Semakin besar kewajiban yang harus dibayarkan dengan equity yang dimiliki oleh perusahaan, maka tingkat financial leveragenya semakin besar yang mengindikasikan risiko atau kegagalan perusahaan dalam membayar hutangnya, sehingga mempengaruhi investor dalam memutuskan investasinya. Untuk current ratio hasil analisis tidak sama dengan hipotesis penelitian, yaitu current ratio berpengaruh positif signifikan terhadap initial return (Susilowati, 2010).

Dari uji simultan (uji F) dihasilkan bahwa variabel bebas secara simultan mampu menjelaskan perubahan pada variabel tergantung atau model dapat dinyatakan cocok atau fit baik untuk saham syariah maupun saham non syariah. Dari uji chow test didapatkan hasil bahwa pengaruh variabel-variabel independen terhadap variabel dependen pada kelompok saham syariah dan non syariah berbeda. Hal ini terjadi karena kondisi, struktur dan elemen kedua sektor tersebut yang berbeda sehingga pengaruhnya terhadap initial return akan berbeda pula.

Untuk perusahaan, hasil penelitian ini dapat dijadikan dasar untuk membuat keputusan dalam membentuk harga dalam menerbitkan saham perdana agar underpricing dapat ditekan. Diharapkan pihak yang terkait dengan pasar modal hendaknya dapat mendorong dan mengembangkan kegiatan investasi syariah di pasar modal, yaitu dengan dilakukannya antara lain program sosialisasi secara intensif tentang kegiatan investasi syariah di pasar modal yang mencakup antara lain, prinsip-prinsip dasar, produk, mekanisme transaksi, peraturan dan pola pengawasan, penyusunan kerangka peraturan yang lebih jelas dalam rangka penerbitan efek syariah dan kegiatan investasi syariah di pasar modal, dan membentuk pola kelembagaan (hubungan antara Bapepam, SROs, DSN, dan Profesi) yang efisien dalam fungsi dan peran dalam mengatur, membina, mengawasi, dan menjalankan kegiatan investasi syariah di pasar modal Indonesia.

\section{PUSTAKA ACUAN}

Afriyanti, M. 2011. Analisis Pengaruh Current Ratio, Total Asset Turnover, Debt to Equity Ratio, Sales dan Size Terhadap ROA (Return on Asset). Universitas Diponegoro 
Algifari. 1997. Analisis Regresi, Teori, Kasus dan Solusi. Edisi Pertama. Penerbit: BPFE Universitas Gajah Mada, Yogyakarta

Arifin, Z. 2007. Teori Keuangan dan Pasar Modal. Penerbit: EKONISIA, Yogyakarta

Arman, A. 2012. Pengaruh Umur, Ukuran Perusahaan, Reputasi Underwriter, dan Return on Equity Terhadap Tingkat Underpricing Saham di Bursa Efek Indonesia. Pekan Ilmiah Dosen FEB-UKSW

Balvers, R. J., B. McDonald and R. E. Miller. 1988. Underpricing of New Issues and the Choice of Auditor as a Signal of Investment Bank Reputation. The Accounting Review, Vol. 63, 605-622

Ball, R and P. Brown. 1968. An Empirical Evaluation of Accounting Income Numbers. Journal of Accounting Research, Vol. 6, Issue 2, 159-178

Baron, D.P and B. Holmstrom. 1982. The Investment Banking Contract for News Issues Under Asymmetric Information: Delegation and The Incentive Problem. The Journal of Finance, Vol. XXXV, No. 5

Beatty, Rudolph. P. 1989. Auditor Reputation and Pricing of Initial Public Offerings. The Accounting Review, Vol. LXIV, No. 4

Beatty, R.P and J.R. Ritter. 1986. Investment Banking, Reputation and The Underpricing of Initial Public Offerings. Jounal of Financial Economics 15, 213-232

Brigham, E. F dan J. F. Houston. 2009. Dasar-dasar Manajemen Keuangan, Buku Satu, Edisi Sepuluh. Terjemahan oleh Ali Akbar Yulianto dari Fundamentals of Finance Management (2004). Penerbit: Salemba Empat, Jakarta

Carter, R and S. Manaster. 1990. Initial Public Offerings and Underwriter Reputation. The Journal of Finance, Vol. XLV, No. 4

Chong, T.T. S. Yuan and I.K. Yan. 2010. An Examination of the Underpricing of H-Share IPOs in Hong Kong. Review of Pacific Basin Financial Markets and Policies, Vol. 13. No. 4 (2010) 559-582

Daljono. 2000. Analisis Faktor-Faktor yang Mempengaruhi Initial return Saham yang Listing di BEJ Tahun 1990-1997. Kumpulan Makalah Simposium Nasional Akuntansi III, 556-572.

Darmadji, T dan H.M. fakhruddin. 2001. Pasar Modal di Indonesia, Pendekatan Tanya Jawab. Penerbit: Salemba Empat, Jakarta

Dionysius, S. 2005. Analisis Tingkat Efisiensi Pasar Modal dalam Bentuk Lemah. Tesis Magister Manajemen Universitas Diponegoro

Fahmi, I. 2012. Pengantar Pasar Modal. Penerbit: Alfabeta, Bandung

Fama, Eugene. F. 1970. Efficient Capital Markets: a Review of Theory and Empirical Work. The Journal of Finance, Vol. 25, No.2

Ghozali, Imam. 2009. Ekomometrika: Teori, Konsep, dan, Aplikasi dengan SPSS 17. Badan Penerbit Universitas Diponogoro. Semarang

Hartono, J. 2010. Teori Portofolio dan Analisis Investasi Edisi Ketujuh. Penerbit: BPFE, Yogyakarta

Horne, J.C.V dan J.M. Wachowicz, JR. 2009. Prinsip-Prinsip Manajemen Keuangan. Penerbit: Salemba Empat, Jakarta

Ibbotson, R.G. 1975. Price Performance of Common Stock New Issues. Journal of Financial Economics, Vol. 2

Indah, Rani. 2006. Analisis Pengaruh Informasi Keuangan dan Non Keuangan Terhadap Initial return dan Return 7 Hari Setelah IPO di Bursa Efek Jakarta. Tesis Magister Manajemen Universitas Diponegoro 
Islam, Md. A., R. Ali and Z. Ahmad. 2010. An Empirical Investigation of the Underpricing of Initial Public Offerings in the Chittagong Stock Exchange. International Journal of Economics and Finance, Vol. 2. No. 4. November 2010

Kapoor, S. 2006. Impact of Dividend Policy on Shareholder's Value: a Study of Indian Firms. Doctor of Philosophy in Management. Jaypee Institute of Information Technology University

Khajar, I. 2008. Pengujian Efisiensi dan Peningkatan Efisiensi Bentuk Lemah Bursa Efek Indonesia pada Saat dan Sesudah Krisis Moneter pada Saham-saham LQ-45. Jurnal Manajemen Teori dan Terapan

Keputusan Ketua Badan Pengawas Pasar Modal No. KEP-51/PM/1996 tentang Pedoman Mengenai Bentuk dan Isi Prospektus dan Prospektus Ringkas dalam Rangka Penawaran Umum

Keputusan Ketua Badan Pengawas Pasar Modal No. KEP-43/PM/2000 tentang Perubahan Peraturan Nomor IX.C.3 Tentang Pedoman Mengenai Bentuk dan Isi Prospektus Ringkas dalam Rangka Penawaran Umum

Kim, J.B, I. Krinsky and J. Lee. 1993. Motives for Going Public and Underpricing: New Findings from Korea. Journal of Business Financial and Accounting. January, p. 195-211

Kooli, M and J.M Suret. 2001. The Underpricing of Initial Public Offerings: Further Canadian Evidence. ISSN 1198-8177.

Kristiantari, D.A. 2012. Analisis Faktor-faktor yang Mempengaruhi Underpricing Saham pada Penawaran Saham Perdana di Bursa Efek Indonesia. Tesis Magister Akuntansi Universitas Udayana

Kurnianingsih, H. 2011. Analisis Reaksi Pasar Terhadap Pengumuman Dividen pada Perusahaan Manufaktur. GRADUASI, Vol. 25

Kusuma, H. 2001. Prospektus Perusahaan dan Keputusan Investasi: Studi Empiris Perusahaan yang Terdaftar di Bursa Efek Jakarta. Jurnal Siasat Bisnis, JSB. No. 6. Vol. 1 Th. 2001

Leland, H.E and D.H. Pyle. 1977. Informational Asymmetries, Financial Structure and Financial Intermediation. The Journal of Finance. Vol. XXXII, No. 2

Lintner, John. 1956. Distribution of Incomes of Corporations Among Dividens, Retained Earnings and Taxes. The American Economic Review, Vol. 46, No.2

Mahendra, Alfredo D. J. 2011. Pengaruh Kinerja Keuangan Terhadap Nilai Perusahaan (Kebijakan Dividen Sebagai Variabel Moderating) pada Perusahaan Manufaktur di Bursa Efek Indonesia. Tesis Magister Manajemen Universitas Udayana

Martani, D., I.L. Sinaga dan A. Syahroza. 2012. Analysis on Factors Affecting IPO Underpricing and theirs Effects on Earnings Persistence. World Review of Business Research, Vol. 2. No. 2. March 2012. Pp.1-15

Martani, D dan C. Yolana. 2005. Variabel-variabel yang Mempengaruhi Fenomena Underpricing pada Penawaran Saham Perdana di BEJ Tahun 1994-2001. Makalah Dipresentasikan dalam Simposium Nasional Akuntansi VIII, Solo, 15-16 September 2005

Mulianti, F.M. 2010. Analisis Faktor-faktor yang Mempengaruhi Kebijakan Hutang dan Pengaruhnya terhadap Nilai Perusahaan. Tesis Magister Akuntansi Universitas Dipenonegoro

Murdiyani. 2009. Pengaruh Informasi Prospektus Perusahaan Terhadap Initial return pada Penawaran Saham Perdana (Studi pada Perusahaan LQ-45 2001-2008). Tesis Magister Akuntansi Universitas Dipenonegoro 
Musaroh._Pengujian Efisiensi Setengah Kuat Secara Informasi Terhadap Pengumuman Inisiasi Dividen. Universitas Negeri Yogyakarta

Nurhidayati, S dan N. Indriantoro. 2002. Analisis Faktor-faktor yang Berpengaruh Terhadap Tingkat Underpriced pada Penawaran Perdana di Bursa Efek Jakarta. Bunga Rampai Kajian Teori Keuangan. Penerbit: BPFE, Yogyakarta

PSAK No. 19 (revisi 2009) tentang Aset Tidak Berwujud

Rahmadeni, S. 2012. Analisis Pengaruh Pengungkapan Risiko Kuantitatif dan Kualitatif pada Prospektus Terhadap Initial return. Universitas Indonesia.

Razafindrambinina, D. and T. Kwan. 2013. The Influence of Underwriter and Auditor Reputations on IPO Underpricing. European Journal of Business and Management, Vol. 5. No. 2

Reeve, J. M, C. S Warren dan J. E Duchac. 2009. Pengantar Akuntansi-Adaptasi Indonesia. Buku 1. Penerbit: Salemba Empat, Jakarta

Rock, K. 1986. Why New Issues are Underpriced. Journal of Financial Economics 15. $187-$ 212

Ronni, S. 2003. Problema Anomali dalam Initial Public Offering (IPO). Jurnal Manajemen dan Kewirausahaan Vol. 5. No. 2

Samsul, M. 2006. Pasar Modal dan Manajemen Portofolio. Penerbit: Erlangga, Jakarta

Scott, William. R. 2011. Financial Accounting Theory. $6^{\text {th }}$ ed. Ontario: Pearson Education Canada

Sharma, S.K and A. Seraphim. 2010. The Relationship between IPO Underpricing Phenomenon \& the Underwriter's Reputation. The Romanian Economic Journal, Year XIII. No. 38

Subramanyam, K.R and J.J Wild. 2010. Financial Statement Analysis. Penerbit: Salemba Empat, Jakarta

Suliyanto. 2011. Ekonometrika Terapan: Teori dan Aplikasi dengan SPSS. Penerbit: ANDI, Yogyakarta

Sulistio, H. 2005. Pengaruh Informasi dan Non Akuntansi Terhadap Initial return: Studi pada Perusahaan yang Melakukan Initial Public Offering di Bursa Efek Jakarta. Makalah Dipresentasikan dalam Simposium Nasional Akuntansi VIII, Solo, 15-16 September 2005

Sunariyah. 2006. Pengantar Pengetahuan Pasar Modal. Penerbit: STIM-YKPN, Yogyakarta

Susilowati, Y. 2010. Konsekuensi Signal Prospektus Perusahaan Terhadap Initial return Saham pada Pasar Perdana di Bursa Efek Indonesia. Dinamika Keuangan dan Perbankan Vol. 2, No. 1. Universitas Stikubank

Suwardjono. 2010. Teori Akuntansi Perekayasaan Pelaporan Keuangan. Penerbit: BPFE, Yogyakarta

Tambunan, Andi Porman. 2007. Menilai Harga Saham Wajar. Cetakan ke-7. Penerbit: PT Elex Media Komputindo. Jakarta

Telaumbanua, B. I. K dan Sumiyana. 2008. Event Study: Pengumuman Laba Terhadap Reaksi Pasar Modal. Universitas Gadjah Mada

Triani, A dan Nikmah. 2006. Reputasi Penjamin Emisi, Reputasi Auditor, Persentase Penjamin Emisi, Ukuran Perusahaan, dan Fenomena Underpricing: Studi Empiris pada Bursa Efek Jakarta. Makalah Dipresentasikan dalam Simposium Nasional Akuntansi IX, Padang, 23-26 Agustus 2006

Trisnawati, R. 1999. Pengaruh Informasi Prospektus pada Return Saham di Pasar Perdana. Kumpulan Makalah Simposium Nasional Akuntansi II. Malang

Undang-undang Nomor 8 Tahun 1995 tentang Pasar Modal 
www.bapepam.go.id

www.e-bursa.com diakses 24 Januari 2013

www.iapi.or.id diakses 03 April 2013

www.idx.co.id diakses 14 Februari 2013

www.ojk.go.id diakses 04 April 2013

www.mediaindonesia.com diakses 20 Januari 2013

Yasa, Gerianta. W. 2003. Penyebab Underpricing pada Penawaran Saham Perdana di Bursa Efek Jakarta. Universitas Udayana

Zebua, S. 2012. Faktor-faktor yang Mempengaruhi Fenomena Underpricing pada Penawaran Saham Perdana di Bursa Efek Indonesia dengan Reputasi Penjamin Emisi sebagai Variabel Moderating. Tesis Magister Akuntansi Universitas Sumatera Utara

Zhang, T. 2012. A comparison of Initial Public Offering (IPO) Underpricing between China A-Shares and B-Shares Markets. Master of Finance Program, Saint Mary's University

\section{LAMPIRAN}

Tabel 1. Ringkasan Hasil Uji t

\begin{tabular}{|c|c|c|c|c|c|}
\hline \multirow{2}{*}{\multicolumn{2}{|c|}{ Model }} & \multicolumn{2}{|c|}{ Syariah } & \multicolumn{2}{|c|}{ Non Syariah } \\
\hline & & $\mathrm{t}$ & $\mathrm{t}$ & $\mathrm{t}$ & Sig. \\
\hline \multirow[t]{8}{*}{1} & (Constant) & .188 & .852 & -.270 & .790 \\
\hline & PPS & .169 & .867 & .324 & .750 \\
\hline & NPS & -.773 & .444 & .129 & .899 \\
\hline & EPS & .628 & .534 & 1.487 & .154 \\
\hline & UK & .799 & .429 & -.053 & .958 \\
\hline & RISK & 2.234 & .031 & 1.419 & .173 \\
\hline & FL & -.274 & .786 & 3.294 & .004 \\
\hline & $\mathrm{CR}$ & 1.650 & .107 & 2.406 & .027 \\
\hline
\end{tabular}

Tabel 2. Ringkasan Hasil Uji Koefisien Determinasi dan Uji F

\begin{tabular}{|c|c|c|}
\hline Keterangan & Syariah & Non Syariah \\
\hline Adjusted R Square & .218 & .356 \\
\hline ANOVA: F & 2.797 & 2.971 \\
\hline Sig & $.019^{\mathrm{a}}$ & $.030^{\mathrm{a}}$ \\
\hline RSS Sample: F & 2.797 & 2.971 \\
\hline Sig & $.019^{\mathrm{a}}$ & $.030^{\mathrm{a}}$ \\
\hline
\end{tabular}

Sumber: Hasil SPSS diolah 